\title{
Cost, Returns and Marketing Channels of Paddy in Thiruvarur District (Tamil Nadu)
}

\author{
Dr. Anandaraj. P \\ Assistant professor, Infant Jesus College of Engineering, Tamilnadu
}

\begin{abstract}
This study aims at an appraisal of marketing systems of paddy available for farmers in Thiruvarur district in terms of marketing channels, marketing cost, marketing margin, price spread and marketing efficiency. The Sample consists of 600 farmers who have been classified as small and large farmers according to their land holdings. Proportionate random sampling technique was adopted. In order to identify the key factors of marketing paddy in the study area, a Multiple Linear Regression Model, Garrett's Ranking Technique, Shepherd's Formula, Acharya and Agarwal's Formula and Composite Index Methods were used. The structural differences between small and large farmers were tested by using Chow's F-test. The results revealed the importance of middle man in the chain of marketing that starts with the producer and ends with the consumer. The study has also elucidate fruitful suggestions for the betterment of the farmers, to encourage Government machinery and to avoid exploitations of middle man of Thiruvarur District, TamilNadu.
\end{abstract}

Keywords: Farmers, intermediaries, Marketing channels, Marketing surplus, Price spread and Marketing efficiency, Regulated market, Thiruvarur

\section{Introduction}

Agriculture constitutes the nerve centre of all economic activities in countries - both developed and under-developed - all over the world. In fact the very survival of mankind depends exclusively on the myriad varieties of food grains produced. Of the many kinds of food grain available, paddy (rice) is the most important one, especially in countries like India. Hence, a place of paramount significance has been given to the acceleration and growth of paddy cultivation during the plan periods. This is precisely the reason why the production and marketing of paddy has turned out to be a veritable avenue of research for both explorative and innovative thinkers in recent years.

\section{Statement of the Problem}

Paddy is an important food crop and it has greater economic importance among the food crops, since it is one of the leading commodities in agricultural exports. Hence, the production performance of the crop is of critical importance in improving the efficient use of resources. The cost of production and net returns obtained per unit would determine the profitability of the crop. The profitability of an enterprise depends upon the efficient use of the resources in production. Further, the study of cost and returns structure of paddy would help the farmers in ensuring proper resource combinations to augment the paddy yield, thereby increasing the profits.

Though production is the initiation of the developmental process, it could provide less gain to the producers unless there exists an efficient marketing system. Agricultural marketing is therefore, of greater importance. Commercialisation of agriculture has further increased the importance of marketing. Farmers raise the crops with a hope of receiving fair returns for their hard labour. For this, they depend upon the market conditions, which are not very conducive to fulfill their hopes and expectations. Forced sales, multiplicity of market charges, malpractices in unregulated markets and superfluous middlemen are the problems faced by the farmers. These problems of marketing get further added up by the special features of agricultural commodities namely, their inelastic demand, seasonality in supply, spatially scattered production, bulkiness and perishability.

The market imperfection and the consequent loss in marketing efficiency are more pronounced in markets for perishable commodities which require quick transportation and better storage facilities, involving large number of intermediaries who take away high margins from the price paid by consumers. Paddy has a pride not only for its diverse uses but also for its special preference by consumers - rich and poor, while it is also subjected to the above stated production and marketing problems. Hence, the present study is an attempt to analyze the production and marketing of paddy in Thiruvarur district.

\section{Objectives of the Study}

The main aim of the study is to analyse costs, returns and marketing channels of paddy in Thiruvarur district. The specific objectives are:

1) To study the characteristics of the sample farmers in the study area namely Thiruvarur district;

2) To estimate the cost and returns structure of paddy cultivation for small and large farms;

3) To analyse the resource productivity and to examine the resource-use efficiency of different factor inputs used in paddy cultivation;

4) To identify the determinants of marketable surplus in paddy;

5) To discuss the existing marketing channels for paddy and to evaluate the marketing cost, marketing margin, price spread and marketing efficiency of different channels; and

6) To study the problems faced by the paddy cultivators in the production and marketing of paddy. 


\section{International Journal of Science and Research (IJSR) \\ ISSN (Online): 2319-7064}

Index Copernicus Value (2013): 6.14 | Impact Factor (2014): 5.611

\section{Methodology}

\subsection{Choice of the study area}

The area chosen for the present study is Thiruvarur district, situated at the southern most tip of Tamil Nadu. Eighty three per cent of its population is residing in villages and 58.8 per cent of its working population is anchored in agriculture and its allied activities. This district stands first in area under cultivation and third in production of paddy among the districts in Tamil Nadu. The area under paddy was 265281 hectares and production was 4,83,125 metric tonnes in 201415 which clearly indicates the importance of paddy in the area. As the soil is fertile more than two crops are raised. Thiruvarur, the District Headquarters, has Needamangalam as a major paddy market. There are many paddy mills in and around Thiruvarur. Hence, the choice of Thiruvarur district as the unit of the present study.

\subsection{Sampling Procedure}

Multistage Stratified Random Sampling Technique has been adopted for the study, taking Thiruvarur district as the universe, the block as the stratum, the village as the primary unit and paddy cultivators as the ultimate unit.

Thiruvarur district comprises 10 blocks. Paddy is mainly cultivated in Thiruvarur, Thiruthuraipoondi and Needamangalam and hence the selection of sample villages was restricted to these three blocks. A list of area under paddy in 2014-15 for all the villages of the three blocks was prepared from the records of the Joint Director of Agriculture, Thiruvarur. Five villages in each block, which account for the highest area under paddy cultivation in the descending order of magnitude, were selected as the study unit for primary data collection.

In order to analyze the marketing costs, marketing margins and price spread, 30 intermediaries, 10 in each category namely village traders, commission agents, wholesalers and retailers were randomly selected. The selected respondents were contacted individually and required information was collected from them.

\section{Collection of Data}

\subsection{Primary Data}

Three separate interview schedules were prepared to collect the required information from the market intermediaries namely the village traders, commission agents and the wholesalers/retailers of paddy. One interview schedule was framed for village traders with a view to collect data related to the price paid and received by them and costs incurred by them in paddy marketing. Second interview schedule was prepared and used for Commission Agents, so as to gather information relating to price paid and received and cost incurred in marketing of paddy. Third interview schedule was prepared for wholesaler or retailer in order to collect cost incurred by them and price paid and received by them in the process of marketing. Particulars regarding the method of purchase, cost of marketing, expenditure incurred on establishment charges, commission, prices paid and received and the like were collected.

\subsection{Secondary Data}

Secondary data were collected from:

(i) Directorate of Economics and Statistics, Government of Tamil Nadu, Chennai.

(ii) Office of Assistant Director of Economics and Statistics, Thiruvarur District.

(iii) Office of the Thiruvarur District Market Committee, Thiruvarur.

(iv) Office of the Joint Director of Agriculture, Thiruvarur.

In addition to that, books, journals and magazines were referred. Journals such as Indian Journal of Agricultural Marketing, Indian Journal of Agricultural Economics, Agricultural Marketing, Indian Journal of Marketing and other relevant Journals were referred to for collecting secondary data for the study.

Secondary sources of data relating to location, climate, rainfall, soil type, land utilization pattern, production, yield of major crops, cropping pattern, infrastructural facilities and the like were collected from the office of the Assistant Director of Economics and Statistics, District Collectorate, Thiruvarur.

\section{Method of Analysis}

Keeping in view the objectives of the study, 600 sample cultivators were stratified into two categories namely small and large farmers. The farmers with less than five acres were grouped as small farmers and farmers possessing five or more acres were grouped as large farmers. Out of 600 sample respondents, 416 (69.33 per cent) cultivators came under the category of small farmers and remaining 184 (30.67 per cent) fell under the group of large farmers.

\section{Tools of Analysis}

In order to identify the factors influencing the gross returns of paddy, a Multiple Log-Linear Regression Model and Cobb-Douglas type was fitted. The structural differences between small and large farmers were tested by using Chow's F-test.

In order to find out the structural difference that existed at slope level and/or at intercept level, a Multiple Log-Linear Regression Model with slope and intercept dummy variables was used.

To find out resource use efficiency of factor inputs, marginal value productivities of each of the input variables for small and large farms were compared and equated with their acquisition cost.

To identify the factors which influence the marketable surplus and net gains earned by paddy cultivators, a Multiple Linear Regression Model was used.

To examine the marketing efficiency of the various marketing channels, Shepherd's Formula, Acharya and 


\section{International Journal of Science and Research (IJSR) \\ ISSN (Online): 2319-7064}

Index Copernicus Value (2013): 6.14 | Impact Factor (2014): 5.611

Agarwal's Formula and Composite Index Methods were used. The Efficiency Index formula used by Calkins and Weston was applied to measure the marketing efficiency index.

Garrett's Ranking Technique was adopted in order to rank the problems faced by the cultivators in production and marketing of paddy respectively.

The behaviour of prices and arrivals of paddy was analyzed by computing ratio to moving average method and Residual Method. Trend and Linear Growth Rates were worked out for analysing secular trend behaviour of prices and arrivals. To study the variations due to trend, cyclical, seasonal and irregular fluctuations, coefficients of variations were computed.

Price-spread analysis works out the share of different market functionaries in the consumer rupee and would often throw light on the relative efficiencies of alternative channels of marketing. Price-spread is measured by using concurrent margin method where margin was derived as the difference between the price paid by the ultimate consumer and price received by the producer.

\section{Results and Analysis}

Market structure includes the various marketing channels, agent's intermediaries and traders involved in moving the produce from the producers to the consumers or users. In the present study, market structure includes different market channels, intermediaries such as village traders, wholesalers, retailers, millers and consumers. The most common marketing channels identified in paddy marketing in the Thiruvarur district are:

\section{MARKETING CHANNELS}

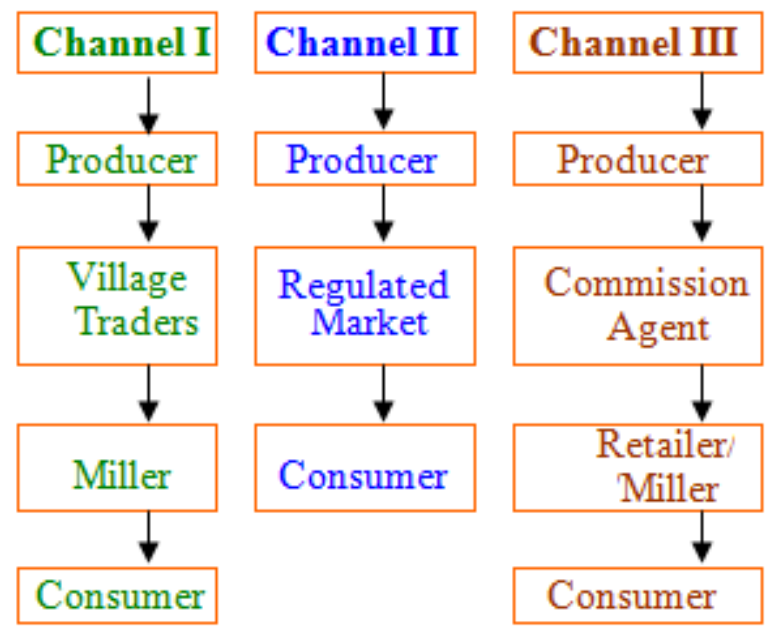

The results on the percentage of retention and marketable surplus of the selected farmers producing paddy given in table 8.1 reveal that the variation in the percentage of marketable surplus to production among the group was found to be minimum.
Table 8.1: Marketable Surplus of Paddy, (Quintals per acre)

\begin{tabular}{|c|c|c|c|c|}
\hline $\begin{array}{c}\text { Size of } \\
\text { Farmers }\end{array}$ & $\begin{array}{c}\text { Total } \\
\text { Production }\end{array}$ & $\begin{array}{c}\text { Total } \\
\text { Retention }\end{array}$ & $\begin{array}{c}\text { Total } \\
\text { Marketable } \\
\text { Surplus }\end{array}$ & $\begin{array}{c}\text { Percentage of } \\
\text { total } \\
\text { production }\end{array}$ \\
\hline Small & 24.15 & 1.98 & 22.17 & 91.80 \\
\hline Large & 22.61 & 2.61 & 20.00 & 88.46 \\
\hline Overall & 46.76 & 4.59 & 42.17 & 90.18 \\
\hline
\end{tabular}

Source: Survey Data.

Also It is understood from Table 8.2 that the percentage of quantity stored to the marketable surplus of paddy stored is marginal with 29.05 per cent in the case of small farmers while it is 27.60 per cent in the case of larger farmers.

Table 8.2: Marketable Surplus and Storage Of Paddy, (Quintals per acre)

\begin{tabular}{|c|c|c|}
\hline & $\begin{array}{c}\text { Small } \\
\text { Farmers }\end{array}$ & $\begin{array}{c}\text { Large } \\
\text { Farmers }\end{array}$ \\
\hline Marketable Surplus & 22.17 & 20.00 \\
\hline Quantity Stored & 6.88 & 7.60 \\
\hline $\begin{array}{c}\text { Percentage of Quantity Stored } \\
\text { to Marketable Surplus }\end{array}$ & 29.05 & 27.60 \\
\hline
\end{tabular}

Source: Computed Data.

\subsection{Choice of the Intermediaries}

The net price realised by the farmers as shown in Table 8.3 is ultimately the result of factors like the duration of storage and the role of the agent or the merchant middlemen through or to whom the produce is sold.

Table 8.3: Middlemen Chosen by the Sample Farmers

\begin{tabular}{|c|c|c|c|}
\hline Middlemen & $\begin{array}{c}\text { Small } \\
\text { Farmers }\end{array}$ & $\begin{array}{c}\text { Large } \\
\text { Farmers }\end{array}$ & Total \\
\hline Village Traders & $\begin{array}{c}78 \\
(18.75)\end{array}$ & $\begin{array}{c}63 \\
(32.61)\end{array}$ & $\begin{array}{c}138 \\
(23.0)\end{array}$ \\
\hline Regulated Markets & $\begin{array}{c}66 \\
(15.87)\end{array}$ & $\begin{array}{c}23 \\
(14.13)\end{array}$ & $\begin{array}{c}92 \\
(15.33)\end{array}$ \\
\hline Commission Agents & $\begin{array}{c}272 \\
(65.38)\end{array}$ & $\begin{array}{c}98 \\
(53.26)\end{array}$ & $\begin{array}{c}370 \\
(61.67)\end{array}$ \\
\hline Total & 416 & 184 & 600 \\
& $(100)$ & $(100)$ & $(100)$ \\
\hline
\end{tabular}

Source: Survey Data. Figures in brackets are the percentage of the total.

From the Table it is clear that the commission agents are the most preferred middlemen by the small farmers compared to the large farmers because of the facilities offered by them.

\subsubsection{Sale to Regulated Markets}

The direct channel which has no middleman is the regulated markets. But this channel is not very popular among the farmers because of various reasons. The number of farmers and quantity of paddy sold to the regulated markets are presented in Table 8.4

Table 8.4: Number of Farmers and Quantity of Paddy Sold Through Regulated Markets, (Quintals per acre)

\begin{tabular}{|c|c|c|c|c|}
\hline $\begin{array}{c}\text { Size of } \\
\text { Farmers }\end{array}$ & $\begin{array}{c}\text { Number } \\
\text { of } \\
\text { Farmers }\end{array}$ & $\begin{array}{c}\text { Percentage } \\
\text { of group } \\
\text { concerned }\end{array}$ & $\begin{array}{c}\text { Average quantity } \\
\text { of paddy sold (in } \\
\text { quintals per acre) }\end{array}$ & $\begin{array}{c}\text { Percentage of } \\
\text { marketed surplus } \\
\text { of the group } \\
\text { concerned }\end{array}$ \\
\hline Small & 66 & 15.86 & 3.25 & 15.27 \\
\hline Large & 26 & 14.13 & 2.49 & 13.16 \\
\hline Overall & 92 & 15.33 & 5.74 & 14.29 \\
\hline
\end{tabular}




\section{International Journal of Science and Research (IJSR) \\ ISSN (Online): 2319-7064}

Index Copernicus Value (2013): 6.14 | Impact Factor (2014): 5.611

Source: Computed Data.

The average quantity of paddy sold per acre by small and large farmers is 3.25 and 2.49 quintals respectively. The percentage to the marketed surplus of the group concerned namely small and large farmers is 15.27 and 13.16 per cent respectively.

\subsubsection{Sale to Commission Agents}

The most popular and dominant channel in the district is the commission agent. The commission agent advances loans with or without interest to the farmers, whenever they need money for their cultivation. The number of farmers and quantity of paddy sold through commission agents are presented in Table 8.5.

Table 8.5: Number of Farmers and Quantity Of Paddy Sold Through Commission Agent, (Quintals Per Acre)

\begin{tabular}{|l|c|c|c|c|}
\hline $\begin{array}{c}\text { Size of } \\
\text { Farmers }\end{array}$ & Number of Farmers & $\begin{array}{c}\text { Percentage of } \\
\text { group concerned }\end{array}$ & $\begin{array}{c}\text { Average quantity of paddy } \\
\text { sold (in quintals per acre) }\end{array}$ & $\begin{array}{c}\text { Percentage of marketed surplus of } \\
\text { the group concerned }\end{array}$ \\
\hline Small & 272 & 65.38 & 14.13 & 66.37 \\
\hline Large & 98 & 53.26 & 10.56 & 55.84 \\
\hline Total & 370 & 61.67 & 24.69 & 61.42 \\
\hline
\end{tabular}

Source: Computed Data.

The percentage of quantity sold to marketed surplus is 66.37 and 55.84 per cent of their respective total in the case of the small and the large farmers respectively.

\subsection{Analysis of Price Spread of Small Farmers}

Price spread analysis shows details about the producer's price, marketing margin, marketing cost and consumer price in three marketing channels. The analysis of price spread in the three marketing channels for small farmers is given in Table 8.6

Table 8.6: Price Spread Of Small Farmers Under Different Channels, (Rupees per quintal)

\begin{tabular}{|c|c|c|c|}
\hline \multirow{2}{*}{ Particulars } & \multicolumn{3}{|c|}{ Channels } \\
\cline { 2 - 4 } & $I$ & II & III \\
\hline Producers price & 559.11 & 579.14 & 586.16 \\
\hline Marketing Margin & 92.37 & 68.53 & 119.67 \\
\hline Marketing cost & 202.54 & 206.35 & 148.19 \\
\hline Consumer's price & 854.02 & 854.02 & 854.02 \\
\hline Price spread & 294.22 & 274.88 & 267.86 \\
\hline
\end{tabular}

Source: Computed Data.

It is seen from Table 8.6 that the price spread is at a minimum of Rs.267.86 per quintal in channel III and a maximum of Rs.294.22 in channel I.

\subsection{Analysis of Price Spread of Large Farmers}

The analysis of price spread for large farmers is presented in Table 8.7
Table 8.7: Price Spread Of Large Farmers Under Different Channels, (Rupees per quintal)

\begin{tabular}{|c|c|c|c|}
\hline \multirow{2}{*}{ Particulars } & \multicolumn{3}{|c|}{ Channels } \\
\cline { 2 - 4 } & I & II & III \\
\hline Producers price & 642.25 & 598.89 & 642.87 \\
\hline Marketing Margin & 65.55 & 66.12 & 85.39 \\
\hline Marketing cost & 146.22 & 189.01 & 125.76 \\
\hline Consumer's price & 854.02 & 854.02 & 854.02 \\
\hline Price spread & 211.77 & 255.13 & 201.15 \\
\hline
\end{tabular}

Source: Computed Data.

It is seen from Table 8.7 that the price spread is at a minimum of Rs.201.15 per quintal in channel III and a maximum of Rs.255.13 in channel II.

The results of price spread analysis show the similarities in the case of small as well as large farmers in channel II. But the large farmers have a lesser price spread than the small farmers in marketing channels I and III because of their financial strength, large scale production and lesser average fixed overheads.

\subsection{Composite Index Method}

The marketing efficiency was also analyzed by using composite Index Method. The percentage of producer's price, marketing cost and marketing margin to consumer's price per quintal were calculated and these were assigned ranks. Total scores were found by adding the respective ranks in each channel. The mean score was calculated for each channel. Where the mean score is less, it showed the real marketing efficiency of the channel. The computed results are given in Table 8.8

Table 8.8: Marketing Efficiency Analysis Using Composite Index Method, (Rupees per quintal)

\begin{tabular}{|c|c|c|c|c|c|c|}
\hline \multirow{2}{*}{ Particulars } & \multicolumn{9}{|c|}{ Channels } & \multicolumn{2}{c|}{ II } & \multicolumn{2}{c|}{ III } \\
\cline { 2 - 7 } & \multicolumn{2}{|c|}{$I$} & Large & Small & Large \\
& Small & $\begin{array}{c}\text { Large } \\
\text { farmers }\end{array}$ & $\begin{array}{c}\text { Small } \\
\text { farmers }\end{array}$ & $\begin{array}{c}\text { Larmers } \\
\text { farmers }\end{array}$ & farmers \\
\hline Producer's share & 65.47 & 75.20 & 67.81 & 70.13 & 68.64 & 74.10 \\
Rank & 3 & 2 & 2 & 3 & 1 & 1 \\
\hline Marketing cost & 202.54 & 146.22 & 206.35 & 189.01 & 140.19 & 125.76 \\
Rank & 2 & 2 & 3 & 3 & 1 & 1 \\
\hline Marketing Margin & 92.37 & 65.55 & 68.53 & 66.12 & 119.67 & 85.37 \\
Rank & 2 & 2 & 1 & 1 & 3 & 3 \\
\hline Total Score & 7 & 6 & 6 & 7 & 5 & 5 \\
\hline Mean score & 2.33 & 2 & 2 & 2.33 & 1.67 & 1.67 \\
\hline
\end{tabular}

Source: Computed Data. 


\section{International Journal of Science and Research (IJSR) \\ ISSN (Online): 2319-7064 \\ Index Copernicus Value (2013): 6.14 | Impact Factor (2014): 5.611}

It is observed from Table 8.8 that of the three channels, channel III has more marketing efficiency than channel I and II. Even though the producers' share in channel II is greater than that in channel I, the marketing cost is higher in channel II than channel I. There is no variation in the results of marketing efficiency of large and small farmers.

\section{Major Findings}

The major findings of the study are:

The size of operational holdings ranged from 0.5 acres to 4.6 acres with a mean 2.43 acres per farm in the case of small farmers, whereas in the case of large farmers it ranged from 5.20 to 9.78 acres with a mean of 6.72 acres.

Regarding the cropping pattern, food crops like paddy, tapioca, oil seeds such as groundnut and coconut and commercial crops like cashew, rubber, fruits and spices are raised. Paddy is the most predominately cultivated food crop in the district.

The farmers, with an experience of more than 5 years in the cultivation of paddy were found to be 68 per cent. Hence, this long term association of farmers with the cultivation of paddy led to better productivity and maximum profit in paddy cultivation.

The input-output structure revealed that there was a significant variation in terms of yield in quintals per acre between the small and the large farmers. The yield per acre was $2419.25 \mathrm{kgs}$. of paddy in the case of the small farmers and 2274.55 quintals in the case of the large farmers. Hence, it is concluded that the small farmers produced higher yield than the large farmers.

As regards the use of inputs, significant difference between the two groups of farmers was found in the case of human labour and chemical fertilizers. With regard to the use of other variable inputs namely bullock labour, farm yard manure, pesticides, irrigation and seed, the difference was only marginal.

It is also observed from the analysis that except the expenditure on human labour and interest on working capital, other inputs exhibited the same pattern for both type of farmers. The analysis of cost-benefit ratio revealed that each rupee spent resulted in a benefit of Rs.0.39 in the case of the small farmers and Rs.0.36 in the case of the large farmers.

Therefore, it may be concluded from the analysis of cost and returns structure that the small farmers benefited more in terms of both yield and net returns per acre. This could be the outcome of better economies and institutional position of the small farmers compared with the large farmers in the study area.

The results of regression equation fitted to the different categories of farmers as well as to the pooled category have significantly explained that the variables influencing the gross returns of paddy were human labour, fertilizers, area under paddy and capital flows. Among these significant variables, human labour had a greater influence on the gross returns of paddy. Further, the results indicated that the returns of paddy cultivators could be increased with a greater use of the aforesaid inputs. The regression model fitted was highly significant in all categories of farmers.

In order to examine the structural difference between the small and the large farmers, Chow's test was applied. The results revealed that there existed a structural difference between the two groups only at the slope level. At the slope level, variable factors like human labour and capital flow were responsible for the differences in the gross returns. At the intercept level, the co-efficient of dummy variable was not statistically significant. It implies that there was no difference with regard to technical change in both groups.

The working out of the ratios of marginal value products to their respective cost with respect to human labour, bullock labour, fertilizer and capital flows of the small farmers and human labour, bullock labour, fertilizers and capital flow in the case of the large farmers were greater than unity. It shows that farmers are rational in terms of their response to economic opportunities and make adjustments in resourceuse. The presence of an excess marginal value product over respective factor cost indicates the unexploited economic margins in the cultivation of paddy. Hence, it may be concluded that there is scope for increasing the use of such resource-inputs in paddy cultivation for both groups of farmers to maximise their returns.

The Garrett's ranking technique was applied to identify the factors affecting paddy cultivation and it was found that severity of diseases, pest attacks and the like were the major hurdles for both the small and the large farmers in paddy cultivation in the study area. This makes it very necessary that the farmers cultivating paddy should adopt the required level of pest-control measures in the cultivation of paddy.

The results of marketing efficiency computed by the Shepherd's formula, Acharya and Agarwal's formula and the Composite Index Method showed that Channel III Producer-commission agent - Retailer/Miller-consumer, was the most efficient channel in paddy marketing in Thiruvarur district.

The Garrett's ranking technique was adopted to identify the major problems in the marketing of paddy. It was found that the fluctuation in prices stood first in the ranking followed by heavy commission charges and lack of finance.

\section{Few Suggestions \& Conclusion}

In the present study, the marginal value product is greater than the respective factor cost in the cultivation of paddy. There is existence of unexploited economic surplus and there is scope for effective utilisation of resources in the cultivation of paddy for both groups of farmers to maximise the yield of paddy. Hence, it is suggested that the Government of Tamil Nadu should direct the co-operation and support of the Tamil Nadu Agriculture University for creating awareness for the efficient use of resources in paddy cultivation. The government may arrange periodical seminars and training programmes in which farmers should

\section{Volume 4 Issue 11, November 2015}




\section{International Journal of Science and Research (IJSR) \\ ISSN (Online): 2319-7064}

Index Copernicus Value (2013): 6.14 | Impact Factor (2014): 5.611

be imparted adequate and improved training in paddy cultivation practices at regular intervals of time. Lack of awareness of such practices ultimately resulted in a low level of production and unjustified profit margins with respect to paddy.

\section{References}

[1] Acharya, S.S and Agarwal, N.L., Agricultural Marketing in India, Oxford and IBH Publishing Company, New Delhi, 1987

[2] Jain, S.C., Principles and Practices of Agricultural Marketing and Prices, Vora and Company, Pvt. Ltd., Bomabay, 1997

[3] Hanumantha Rao, Changes in Costs and Returns with the Use of High Yielding Seeds, Technological Change and Distribution of Gains in Indian Agriculture, Macmillan Company of India Ltd., Delhi, 2005

[4] Venkatraman, J.C. "Price-spread of Agricultural Commodities in RecentYears", Indian Journal of Agricultural Economics, 234 (4), 2014.

[5] Videv, V. "Improvement of Spatial Distribution of Vine Growing: An Important Factor in Raising Production Efficiency", World Agricultural Economics and Rural Sociology Abstract, Vol.XIX, No.8, 1999.

[6] Yadav, J.S. Regulated Markets and their Functional Performance - A Case Study of Grain Market of Tamil Nadu", Indian Journal of Agricultural Marketing, Vol.12, No.3, September - December 2002.

\section{Reports}

[7] Credit Plan for Thiruvarur District 2014-15 \& Annual Action Plan, 2015.

[8] AGROSTAT, Joint Director of Agriculture, Thiruvarur, 2012 ,State Bank of India Thiruvarur District

[9] Forty nine Annual Report of Thiruvarur District Cooperative Bank Ltd., 2014-15.

[10] "G" Report of Thiruvarur District, 2014-15, District Statistical Office, Thiruvarur, Report of Public Works Department Office, Thiruvarur.

[11] Soils of Thiruvarur District - Tamil Nadu, Soil Survey and Land Use Organisation, Thanjavur.

[12] Statistical Hand Book, District Statistical Office, Thiruvarur. Statistical Hand Book of Tamil Nadu, 2014.

[13] Studies in Economics of Farm Management in Thanjavur District, Directorate of Economics and Statistics, Tamil Nadu, Report for the year 2014-15.

\section{Websites}

[14] www.emeraldinside.com

[15]www.googlee.com

[16] www.india.agronet.com

[17] www.tn.gov.in.com 